This PDF is a selection from a published volume from the National Bureau of Economic Research

Volume Title: Demography and the Economy

Volume Author/Editor: John B. Shoven, editor

Volume Publisher: University of Chicago Press

Volume ISBN: 0-226-75472-3

ISBN13: 978-0-226-75472-7

Volume URL: http://www.nber.org/books/shov08-1

Conference Date: April 11-12, 2008

Publication Date: November 2010

Chapter Title: Aging Populations, Pension Operations, Potential Economic Disappointment and Its Allocation

Chapter Authors: Sylvester J. Schieber

Chapter URL: http://www.nber.org/chapters/c8418

Chapter pages in book: $(293$ - 325) 


\title{
Aging Populations, Pension Operations, Potential Economic Disappointment, and Its Allocation
}

\author{
Sylvester J. Schieber
}

\subsection{Introduction}

Much has been written about population aging and its economic implications. A great deal of this discussion has focused on the retirement systems that exist in various parts of the world and how they will fare under the aging phenomenon. Some analysts conclude that we must radically modify many of the retirement systems now in operation in order to deal with new economic realities that are unfolding before us.

There are many instances where the adjustment of pension policy to address the population aging issue has been to move systems that have been traditionally financed on a pay-as-you-go basis more toward being funded. A case can be made that the United States did this in the early 1980s when policymakers adopted legislation that resulted in the build-up of the Social Security trust funds from nearly nothing in 1983 to more than $\$ 2$ trillion today. Chile did this when it abandoned its traditional pay-as-you-go defined benefit pension for an individual account program in the early 1980s. Australia followed suit in the 1990s. Sweden did not go as far as Australia or Chile but implemented a pension reform that included a 2.5 percent of covered payroll mandatory defined contribution account for all workers. Canada followed the U.S. lead in the 1990s, to an extent, by increasing the funding of its national pension during its post-World War II baby boom generation's working career but took a very different path on how the accumulating assets

Sylvester J. Schieber is retired from Watson Wyatt Worldwide and currently works as an independent consultant.

The analysis and conclusions presented here are the author's and should not be attributed to anyone else. I wish to thank Steven Nyce of Watson Wyatt Worldwide for his help with various computations presented throughout the chapter and Steven Venti for helpful comments on the chapter at the time of its presentation. 
would be invested. Germany also moved toward greater pension funding, but more passively, by limiting the cost of their pay-as-you-go national pension with the implication that reduced future benefits under the new cost constraint would result in workers saving more to meet their own retirement needs in the future.

While many countries have changed their course on funding their retirement systems, it is not always clear that the economic results are as straightforward as they might seem on the surface. In the next section of the chapter, we explore the alternative economic perspectives of pension funding. From a microeconomic perspective, many workers may not discern any practical effect from the restructuring of the approach to financing their pensions. Even from a macroeconomic perspective, there are questions over whether some of the move toward pension funding that has arisen in recent years is more cosmetic than real.

In virtually every case in which a country has adopted policies in recent years to increase the funding of their future retirement claims, a major motivation has been to ameliorate the economic implications of population aging. Axel Börsch-Supan (this volume) shows that moving to a savings based retirement system improves the economic outlook that even rapidly aging countries face. To date, however, there has been relatively little analysis of whether pension funding has the potential to provide the sort of economic growth that citizens in many of the developed countries of the world have come to expect. In the third section of this chapter, we explore some of the implications of diverse demographic scenarios under pay-as-you-go versus funded pension systems.

A fundamental economic issue that population aging may pose in many societies is that their labor forces will grow more slowly in the future than in the past. This slower labor force growth has two important implications. First, labor force growth rates are one of the primary drivers that underlie economic growth. Slower labor force growth will mean slower economic growth and diminished contributions to improving living standards that have been realized in virtually all developed economies of the world since the end of World War II. Second, a growing aged population in the face of a stable or diminished workforce implies significant increases in aged dependency. The combination of these forces will limit future growth in living standards in the developed economies of the world. In the fourth section of the chapter, we explore how the pension systems may be used to allocate the economic disappointment that aging societies will face unless they can find policies that will grow the economic resources available to them.

If our economies cannot meet public expectations about economic performance, the method for allocating the disappointment is an important policy issue. In that regard, pension policy may play a significant role although other means of partially addressing the matter may be available to policymakers. Many retirement systems have been structured traditionally to 
provide retirees with increasing levels of benefits linked to growing wages or workers' productivity levels. If total output in an economy is unsatisfactory but retirees are allocated benefits directly correlated to rising worker productivity, then workers and their dependents will be disappointed. Our ability to encourage workers to achieve even higher levels of productivity may be significantly limited if we cannot reward them for the added contribution. On the other hand, if we let workers enjoy the fruits of their rising productivity rates, we run the risk that retirees' standards of living might actually fall from one generation to the next. If neither outcome is viewed as satisfactory, one alternative is to encourage higher levels of labor force participation from all segments of the population beyond normal school ages.

Some societies may attempt to address the aging issue by shifting from pay-as-you-go financing of their pension systems to prefunded arrangements. Our analysis suggests that some countries face such significant demographic shifts toward older populations that this will offer little practical relief. In these cases, the whole concept of retirement that has persisted over much of the past century may need to be revisited.

\subsection{Retirement Plans as a Consumption Allocation Mechanism}

Retirement systems are income transfer mechanisms that facilitate the distribution of goods and services produced by workers to the elderly, nonworking members of a society. At a given point in time, the utilization and productivity of labor and capital limit the total output in an economy. Workers receive their share of output in the form of wages. Owners of capital receive their share of output in the form of returns on their investments. Retirees can receive a share of output either through their ownership rights of capital or from transfers from the wages paid to workers.

In the first type, the capital-based retirement system, workers accumulate their ownership of capital during their working career. They do so by saving a portion of their earnings along with employer contributions and letting the total savings accumulate with interest until they retire. During retirement, retirees liquidate their assets to finance their consumption needs. In this regard, the retirement plan is a mechanism to transfer consumption rights across time periods. This intertemporal transfer of consumption is accomplished by the buying and selling of assets. Accruing pension liabilities are "funded" as the rights to future pension benefits are earned in defined contribution plans. In funded defined benefit plans, they are approximately funded on the basis of actuarial estimates of what is required to meet future obligations as they are earned.

Financing retirees' consumption through intergenerational transfers can take place either on an informal basis or through more formal arrangements. The informal arrangements are typically worked out within families, where a younger generation commits to support its elders when they are no lon- 
ger able to work. Governments generally sponsor formal arrangements although some employers sponsor retirement plans that are intergenerational rather than intertemporal transfer mechanisms. These plans are known as pay-as-you-go plans because they take money from current workers' production and transfer it to current retirees.

In both capital-based and pay-as-you-go plans, workers forego some current earnings and, thus, some portion of consumption during the earning period to finance retirement consumption. In funded retirement vehicles, workers do this by purchasing assets that earn returns while held and that are sold in retirement. In pay-go retirement systems, workers do it by surrendering a share of their earnings, which are then transferred to retirees.

\subsubsection{Retirement Savings and Personal Wealth Accumulation}

To show how alternative pension financing structures operate from a worker's perspective, consider an example of a worker who begins a career at age twenty-five earning $\$ 35,000$ per year. Assume this individual has perfect foresight and knows that his pay will increase 4 percent per year until he reaches age sixty-five, when he will retire and receive a pension that is 70 percent of his disposable income. His disposable income is his total wage minus what he has to contribute to a pension in order to finance his retirement income. To simplify the process of determining how much the worker should save, we assume he knows that he will live to be 81.5 years of age. We also assume the worker anticipates receiving an annual rate of return on his assets of 5 percent per year.

If everything goes according to plan, this worker will earn roughly $\$ 161,600$ in his last year of employment. After his retirement savings are put aside, his disposable income will be approximately $\$ 135,700$ that year. As it turns out, this worker will need to save 16 percent of his annual earnings each year in order to fulfill his work and retirement plans. If he does that, he should be able to receive an annuity of $\$ 113,100$ per year for each year of retirement, 70 percent of his final year's earnings, or about 83 percent of disposable income in his final year of work. This pattern of asset accumulation and net balances are reflected in figure 8.1.

Over the working period, the worker's steady saving plus interest accruing on accumulated assets gradually accelerates the growth in assets. From a macroeconomic perspective, contributions to the plan are reflected as savings accruing in the economy. After retirement, the assets are steadily depleted over the worker's remaining lifetime and run out when he dies. Net savings over the worker's lifetime, in this example, are zero. Had he wished to leave a bequest to heirs, the worker would have had to save more during his working life or spend less during retirement.

If the same worker described in the preceding is covered by a pay-go retirement plan, the dynamics of his accumulating retirement wealth are considerably different than in a funded pension plan. First, his annual contributions 
to the retirement system are paid out to current retirees. Second, rather than becoming part of an accumulation of capital that can be invested in the economy, in most cases his contributions merely purchase an entitlement to a benefit at retirement age. The pattern of this transaction is reflected in figure 8.2, which turns out to be a mirror image of figure 8.1. In this case, the "accumulated savings" from the worker's perspective is the sum of the obligations owed to the worker. It grows on a gradually accelerating basis until the worker reaches age sixty-five and then is paid off over the remainder of his lifetime as annual retirement benefits.

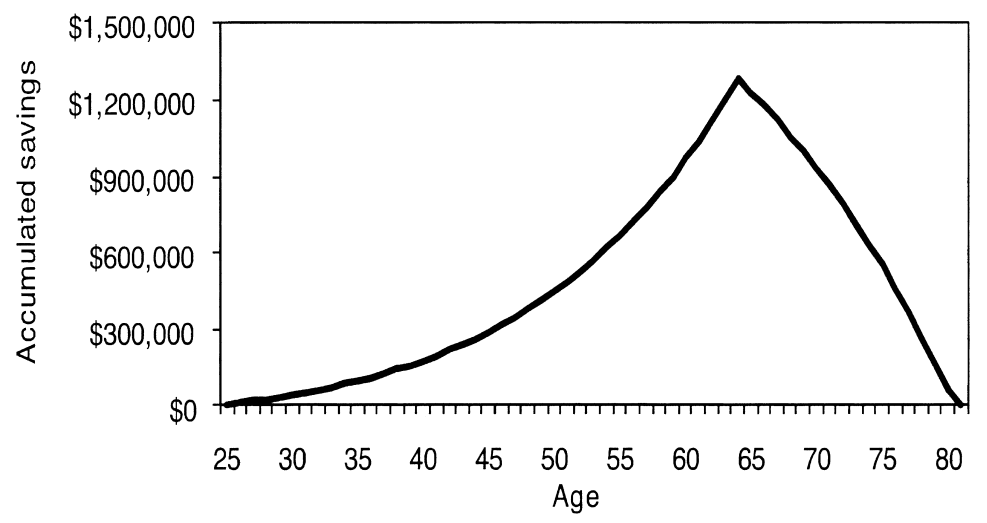

Fig. 8.1 Accumulated savings of a hypothetical worker participating in a funded pension plan

Source: Calculated by the author.

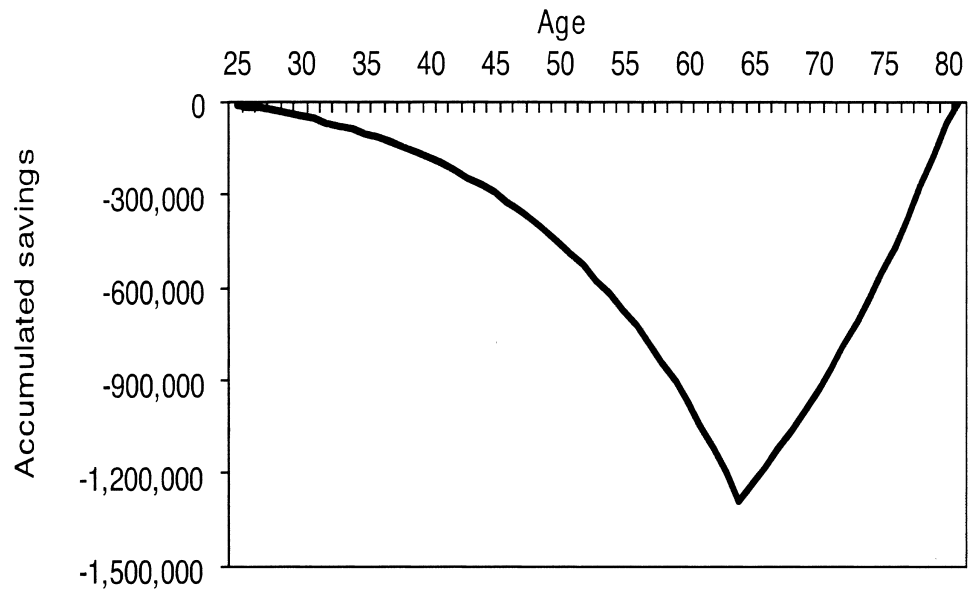

Fig. 8.2 Accumulated savings of a hypothetical worker participating in a pay-asyou-go pension plan

Source: Calculated by the author. 
Table 8.1 Pension operations from a worker's perspective under alternative financing mechanisms

\begin{tabular}{lll}
\hline & \multicolumn{1}{c}{ Pay-as-you-go plans } & \multicolumn{1}{c}{ Funded plans } \\
\hline Workers & $\begin{array}{l}\text { Contribute taxes from wages } \\
\text { Net effect while working } \\
\text { Reduces consumption during } \\
\text { work life }\end{array}$ & $\begin{array}{c}\text { Save from wages to buy assets } \\
\text { Reduces consumption during } \\
\text { work life }\end{array}$ \\
& $\begin{array}{l}\text { Receive benefits from workerss } \\
\text { current taxes }\end{array}$ & $\begin{array}{l}\text { Receive interest and sell assets } \\
\text { to workers }\end{array}$ \\
Net effect while retired & $\begin{array}{c}\text { Use benefit income to finance } \\
\text { consumption }\end{array}$ & $\begin{array}{c}\text { Use asset income to finance } \\
\text { consumption }\end{array}$ \\
\hline
\end{tabular}

Source: Developed by the author.

Pay-as-you-go retirement plans are intergenerational transfer mechanisms. In this case, workers contribute to the plan while working to support contemporary retirees. By contributing to the system during the working career, workers earn "rights" when they retire to have the next generation support their consumption needs. Paul Samuelson, the Nobel laureate economist, characterized these latter plans as "consumption loan" devices (Samuelson 1958). The theory is that when workers pay the payroll tax to support such systems, they forego consumption at the time with the implied understanding that they will be repaid when they reach retirement age.

From the perspective of the worker, the accumulation of pension rights through a pay-go social security system is no different than accumulating wealth through personal savings or a funded pension. The operations of the two types of plans are summarized from a worker's perspective in table 8.1. In both cases, the worker gives up consumption during the working career and stores the value of that foregone consumption in a personal retirement portfolio that is cashed in to support consumption during the retirement period.

The suggestion that these two types of plans are essentially the same in terms of their consumption effects from a worker's perspective is not to suggest that they may have very different real and perceived legal and political risks associated with them. In terms of the dynamics of an individual accruing benefit rights during a working career and receiving benefits during retirement, there is little practical difference. Indeed, there have been many economic analyses of the economic status of individuals approaching retirement that have treated social security wealth, pension, and retirement plan savings and other personal wealth as equivalent (Moore and Mitchell 2000; Poterba, Venti, and Wise 2007).

\subsubsection{Retirement Wealth Accumulation and National Savings}

Over the years, there has been a considerable body of economic research developed regarding the implications of pay-go pensions for national sav- 
ings rates, most of it developed by U.S. economists in the context of the U.S. Social Security program. For example, in 1974, Martin Feldstein estimated that for each $\$ 100$ increase in social security wealth in the United States, private saving was reduced by $\$ 2.10$ (Feldstein 1974). Shortly after his study was released, Dean Leimer and Selig Lesnoy, two analysts working for the U.S. Social Security Administration, discovered a computation mistake in Feldstein's analysis, which they corrected, and extended the computation period. Their estimate was half of Feldstein's and was statistically equivalent to zero (Leimer and Lesnoy 1982). In other words, Leimer and Lesnoy concluded that Social Security had no effect on U.S. savings rates. Feldstein subsequently argued that the difference in results of the two analyses was because Leimer and Lesnoy extended the data series to 1974, without taking into consideration the program changes adopted in 1972 (Feldstein 1982). In 1996, Feldstein updated the model and estimated that a \$1 increase in Social Security wealth reduced savings by two to three cents. While two or three cents may seem trivial, Feltstein estimated that the U.S. Social Security system reduced personal saving by $\$ 416$ billion in 1992 , compared to $\$ 248$ billion of actual savings - a reduction of 63 percent of potential personal saving (Feldstein 1996).

The matter of whether our Social Security program contributes to national savings was somewhat muddied when Congress adopted the provisions in 1983 that have led to a substantial buildup in the trust funds. Table 8.2 shows that since the passage of the 1983 funding requirements, tax revenues flowing into the Social Security trust funds has consistently exceeded expenditures under the program. How this asset buildup is interpreted also is important for thinking about the implications of alternative ways to deal with the program's projected financing shortfalls.

In some circles, the 1983 amendments to the Social Security Act have been regarded as "funding" a portion of the baby boomers' retirement benefits. Since that time, the Social Security trust fund assets have grown from $\$ 31$ billion in 1984 to $\$ 2,048$ billion at the end of 2006, although 47 percent of that growth has been government-credited interest on the accumulating assets, which are held in long-term Federal Government bonds. Despite the substantial growth in the Social Security trust funds over the last twenty years, there has been a considerable debate over whether the accumulating trust fund assets have added to the level of national savings. This debate centers on how holding the accumulating trust fund entirely in government bonds affects the government's other fiscal operations.

The analysts who argue that the U.S. accumulating trust fund has not added to national savings contend that the U.S. government has run larger deficits in its other fiscal operations due to the accumulating trust fund. That is, having the surplus annual revenue available to Social Security relieves policymakers from having to raise funds elsewhere to finance other government operations. A special commission established by President George W. 
Table 8.2

U.S. Social Security cash flows and Federal Government unified budget operations for selected years (in billions of U.S. \$)

\begin{tabular}{|c|c|c|c|c|c|c|}
\hline \multirow[b]{2}{*}{ Year } & \multicolumn{3}{|c|}{$\begin{array}{l}\text { U.S. Social Security trust } \\
\text { fund operations }\end{array}$} & \multicolumn{3}{|c|}{$\begin{array}{l}\text { U.S. Government unified } \\
\text { budget operations }\end{array}$} \\
\hline & $\begin{array}{c}\text { Tax } \\
\text { revenues }\end{array}$ & $\begin{array}{c}\text { Current } \\
\text { expenditures }\end{array}$ & $\begin{array}{l}\text { Net } \\
\text { surplus }\end{array}$ & $\begin{array}{l}\text { Current } \\
\text { receipts }\end{array}$ & $\begin{array}{c}\text { Current } \\
\text { expenditures }\end{array}$ & $\begin{array}{l}\text { Surplus or } \\
(-) \text { deficit }\end{array}$ \\
\hline 1984 & 183.1 & 180.4 & 2.7 & $1,112.5$ & $1,256.6$ & -144.1 \\
\hline 1985 & 197.5 & 190.6 & 6.9 & $1,213.5$ & $1,366.1$ & -152.6 \\
\hline 1986 & 212.8 & 201.5 & 11.3 & $1,289.3$ & $1,459.1$ & -169.8 \\
\hline 1987 & 225.6 & 209.1 & 16.5 & $1,403.2$ & $1,535.8$ & -132.6 \\
\hline 1988 & 255.2 & 222.5 & 32.7 & $1,502.2$ & $1,618.7$ & -116.5 \\
\hline 1989 & 276.7 & 236.2 & 40.5 & $1,626.3$ & $1,735.6$ & -109.3 \\
\hline 1990 & 301.1 & 253.1 & 48.0 & $1,707.8$ & $1,872.6$ & -164.8 \\
\hline 1991 & 307.8 & 274.2 & 33.6 & $1,758.8$ & $1,976.7$ & -217.9 \\
\hline 1992 & 317.2 & 291.9 & 25.3 & $1,843.7$ & $2,140.4$ & -296.7 \\
\hline 1993 & 327.7 & 308.8 & 18.9 & $1,945.8$ & $2,218.4$ & -272.6 \\
\hline 1994 & 350.0 & 323.0 & 27.0 & $2,089.0$ & $2,290.8$ & -201.8 \\
\hline 1995 & 364.8 & 339.8 & 25.0 & $2,212.6$ & $2,397.6$ & -185.0 \\
\hline 1996 & 385.7 & 353.6 & 32.1 & $2,376.1$ & $2,492.1$ & -116.0 \\
\hline 1997 & 413.9 & 369.1 & 44.8 & $2,551.9$ & $2,568.6$ & -16.7 \\
\hline 1998 & 439.9 & 382.3 & 57.6 & $2,724.2$ & $2,633.4$ & 90.8 \\
\hline 1999 & 471.2 & 392.9 & 78.3 & $2,895.0$ & $2,741.0$ & 154.0 \\
\hline 2000 & 504.8 & 415.1 & 89.7 & $3,125.9$ & $2,886.5$ & 239.4 \\
\hline 2001 & 529.1 & 438.9 & 90.2 & $3,124.2$ & $3,056.4$ & 67.8 \\
\hline 2002 & 546.3 & 461.7 & 84.6 & $2,980.7$ & $3,224.0$ & -243.3 \\
\hline 2003 & 546.9 & 479.1 & 67.8 & $3,012.8$ & $3,426.4$ & -413.6 \\
\hline 2004 & 568.7 & 501.6 & 67.1 & $1,880.3$ & $2,293.0$ & -412.7 \\
\hline 2005 & 607.8 & 529.9 & 77.9 & $2,153.9$ & $2,472.2$ & -318.3 \\
\hline 2006 & 642.5 & 555.4 & 87.1 & $2,407.3$ & $2,655.4$ & -248.2 \\
\hline 2007 & & & & $2,568.2$ & $2,730.2$ & -162.0 \\
\hline
\end{tabular}

Sources: U.S. Social Security Administration, 2008 Annual Report of the Board of Trustees of the Federal Old-Age and Survivors Insurance and Federal Disability Insurance Trust Funds, and U.S. Office of Management and Budget, Fiscal Year 2009 Budget of the U.S. Government, Historical Tables.

Bush to make recommendations on Social Security reform fell into this camp. They acknowledged the theoretical possibility that the trust fund accumulation could add to national savings but concluded that the reality since the passage of the 1983 funding legislation had taught the "nation a clear lesson about how unlikely this is as a practice. The availability of Social Security surpluses provided the government with an opportunity to use these surpluses to finance other government spending, rather than saving and investing for the future" (President's Commission to Strengthen Social Security 2001, 38).

Diamond and Orszag (2004), two economists and noted participants in the debate over U.S. Social Security reform, reach the opposite conclusion. They looked at congressional attempts to reduce federal budget deficits 
throughout the 1980s and early 1990s that ultimately resulted in surpluses toward the end of the century. On the basis of the efforts to reduce the unified budget deficits, Diamond and Orszag conclude that it is plausible that U.S. policymakers were not raiding the Social Security surpluses to finance other government operations. In addition, they note that if policymakers were pursuing such a policy, financing general government operations with payroll taxes would have imposed a greater burden on lower-wage workers than financing such operations out of the more progressive U.S. federal income tax. Given that people with lower incomes generally have higher marginal propensities to consume, such a policy would have reduced disposable income for people with high marginal propensities to consume and raised it for people with high marginal propensities to save. The net result would have been to increase the national saving level and reduce consumption levels accordingly.

To some extent, it is impossible to know whether the U.S. Social Security trust fund balance represents wealth that will benefit future generations because the answer partly depends on unobservable or counterfactual behavior. Smetters (2003) argues, however, that by comparing variations in the financing of other government functions to the accumulation in the retirement system over time, we can tell whether the systematic growth in the pension trust funds has been paralleled by changes to the other balances. $\mathrm{He}$ devised an empirical test to see what happened in the United States. The logic of his model is that if the accumulating trust fund has not added to national savings, each dollar of growth in the trust fund should be offset by a dollar increase in the deficit. If the growing pension balances are being saved, then there should be no change in other government net deficits as the pension surplus grows. In his favored specification of the model utilizing data from 1949 through 2002, Smetters found that for every dollar added to the trust funds, the other government net deficits increased by $\$ 2.76$. He concludes that not only are the accumulating Social Security surpluses spent elsewhere in government, but that they act as some sort of accelerator to deficit financing of other government operations.

Nataraj and Shoven (2004) expanded and updated Smetters's analysis. They note that Smetters only looked at the implications of U.S. Social Security trust fund accumulations on other federal fiscal operations. They widened the analysis to include all U.S. government trust funds because the Social Security trusts represent only about half of all government trust funds, and there was considerable correlation between their accumulations over time. In their preferred estimate, Nataraj and Shoven found that a dollar increase in the total federal trust funds increased federal deficits in other operations by $\$ 1.73$, a result that was not statistically different from one. Carrying the analysis further, they broke their analytical period into two periods, 1949 to 1969 and 1970 to 2003. This split was important because in 1970, the U.S. government modified its budgeting procedures to explicitly 
combine the trust fund and other government operations into budget considerations on a unified basis. Before then, each had been considered separately. For the period before the budgets were unified, Nataraj and Shoven found that the accumulating trust funds were not statistically associated with the deficits run in other government operations. After 1970, the accumulating trust funds did lead to added deficits in other government operations, once again statistically on a dollar-for-dollar basis.

Bosworth and Burtless (2004) extended this sort of analysis in another way with two different groups of government entities. First they considered the pension systems sponsored by state governments in the United States for their own employees. At the end of 2000, these state pensions held approximately $\$ 2.3$ trillion in assets, about half the amount held by private employer plans at that time. In this case, they found that as the pension funds increased their holdings by $\$ 100$, the deficits in the states' nonpension accounts increased by about $\$ 8$, an amount statistically equivalent to zero. These state systems are significantly different from the federal Social Security system in that they are not considered in the unified budget context of the federal program. In addition, many of these systems have funding requirements, with contributions held in strictly segregated, trusteed accounts and invested in broadly diversified real assets. Finally, many U.S. state governments have strict balanced budgeting provisions embedded in their constitutions. State-level pension systems in the United States operate much like ordinary funded pensions offered by private-sector employers operating their plans under U.S. legal funding requirements.

In the second part of their analysis, Bosworth and Burtless studied the pension funding in national pension systems and the government deficits associated with other government operations. They had data on thirteen Organization for Economic Cooperation and Development (OECD) countries from the period 1970 through 2000 . They found that a 1 billion currency unit increase in social insurance trust funds increased the government deficit in other operations by 1.26 billion currency units. After adjustments for autocorrelation in their data series, this dropped to 0.57 billion currency units. When they limited the analysis to five countries whose policies require them to fund a portion of their national pensions - Canada, Denmark, Finland, Japan, and Sweden - they estimated the offset at 0.64 billion currency units after adjusting for autocorrelation. In any event, the authors concluded that a unit increase in national pension funding significantly increased net deficits in other government operations.

In the case of employer-sponsored funded retirement plans, there has been an economic debate over whether the tax-preferences accorded retirement savings results in added savings in the economy. For example, Engen, Gale, and Scholz (1996) conclude that tax incentives favoring retirement savings have profound effects on whether savings are in tax-preferred accounts or traditional savings forms but have little or no effect on the level of sav- 
ing. Subsequently, Gale (2005) conceded that tax incentives for retirement savings did have some marginal effect on savings levels but were largely concentrated on higher earners who did not need them and were largely tax shelters rather than saving stimulants. On the other side of this debate, Poterba, Venti, and Wise $(1993,1995,1996)$ evaluate contributions to individual retirement accounts (IRAs) and 401(k) plans from a variety of perspectives and consistently conclude that most of the savings in these plans represent net additions to personal savings.

To date, the statistical studies of the effects of pension saving in funded pensions on personal savings rates are no more conclusive than those examining the savings effects of the pay-as-you-go Social Security pension system. In both cases, there is a general consensus among economists that these plans do reduce other personal savings but probably not dollar for dollar. Because the pay-go systems do not compensate for the reductions in personal savings with the accumulation of real assets, these plans lead to an absolute reduction of savings within the total economy. In the case of funded plans, plan participation should raise savings rates because a unit of pension accrual is matched by a unit of actual savings, and there is only a partial reduction in personal savings.

What would the U.S. government have spent, and, for that matter, what would tax collections have been, without access to Social Security's cashflow surpluses over the last twenty-five years or so? No one knows with absolute certainty, but, that debate notwithstanding, the debate over whether Social Security has affected national savings has been focused too narrowly. In a broader context, the implications of operating a funded versus pay-go pension system are relatively clear. Once again, the U.S. example is a good one because the United States has a relatively large funded pension system that runs parallel to its Social Security system, and there is reasonably good data on both systems that can be compared over time.

A pension system's aggregate contribution to national savings is the extent to which its assets cover its net obligations. It is not the net of the annual contributions into a trust fund minus the payout of current benefits and administrative expenses. It is the extent to which accruing obligations in the plan are covered by the assets in the plan. In the case of private pensions, actuaries are required to estimate the accrued benefit obligations in private plans at each valuation, and plan sponsors are required to report the results to the Federal Government. These periodic tallies of assets and obligations in plans can be used to track the contributions of the system to national savings. Along similar lines, the Social Security actuaries have calculated something they have labeled the "maximum transition cost" for that system in recent years. The actuaries report that this measure "represents the transition cost for continuing the Social Security program in a different form, with all payroll taxes for work after the valuation date credited to the new benefit form. The maximum transition cost is equivalent to the unfunded accrued 
obligation of plan designed to be fully advance funded at the time of plan termination" (Goss, Wade, and Schultz 2008, 3). The tally of assets in the system and the accruing obligations allows us to assess the net effect Social Security is having on national saving.

The results of the Social Security liability calculations and funding levels are presented in the left-hand set of columns in table 8.3. The table shows that while trust fund assets in the Social Security system grew by nearly $\$ 1.5$ trillion between 1996 and 2006, while total obligations increased by $\$ 8.3$ trillion over that same period, with unfunded obligations climbing by $\$ 6.9$ trillion. Some people look at the trust fund growth and conclude that between 1996 and 2006, Social Security contributed \$1.5 trillion to U.S. saving but completely ignore the added $\$ 6.9$ trillion of obligations created for future generations of workers to bear.

To put the results in table 8.3 in perspective, consider a household that begins a year with a bank account balance of zero, runs up a $\$ 20,000 \mathrm{debt}$ over the year and, at year-end, has $\$ 5,000$ in its bank account and a note for the $\$ 20,000$ loan. No one would say that this household has saved $\$ 5,000$. Yet that is exactly the logic behind the claim that the U.S. Social Security program's trust fund accumulation is adding to national savings. In the house-

Social Security and private pension obligations, trust fund assets, and over (under) funding (in billions of U.S. \$)

\begin{tabular}{cccccccr}
\hline & \multicolumn{3}{c}{ Social Security } & & \multicolumn{3}{c}{ Private pensions } \\
\cline { 2 - 3 } Year & $\begin{array}{c}\text { Plan } \\
\text { obligations }\end{array}$ & $\begin{array}{c}\text { Trust fund } \\
\text { assets }\end{array}$ & $\begin{array}{c}\text { System } \\
\text { overfunding }\end{array}$ & & $\begin{array}{c}\text { Plan } \\
\text { obligations }\end{array}$ & $\begin{array}{c}\text { Trust fund } \\
\text { assets }\end{array}$ & $\begin{array}{c}\text { System } \\
\text { overfunding }\end{array}$ \\
\hline 1996 & $9,492.5$ & 567.0 & $-8,925.5$ & & $4,508.4$ & $4,540.5$ & 32.0 \\
1997 & $9,381.8$ & 655.5 & $-8,726.6$ & & $5,150.3$ & $5,307.2$ & 156.9 \\
1998 & $10,274.8$ & 762.5 & $-9,512.3$ & & $5,985.1$ & $6,165.0$ & 179.9 \\
1999 & $11,066.8$ & 896.1 & $-10,170.7$ & & $6,957.1$ & $7,164.1$ & 207.0 \\
2000 & $11,879.3$ & $1,049.4$ & $-10,829.9$ & & $6,704.9$ & $7,286.6$ & 581.8 \\
2001 & $12,919.5$ & $1,212.5$ & $-11,707.0$ & & $6,634.4$ & $6,954.3$ & 319.8 \\
2002 & $13,539.8$ & $1,378.0$ & $-12,161.8$ & & $7,658.0$ & $5,958.3$ & $-1,699.7$ \\
2003 & $14,160.1$ & $1,530.8$ & $-12,629.3$ & & $7,454.1$ & $7,154.8$ & -299.3 \\
2004 & $15,183.0$ & $1,686.8$ & $-13,496.2$ & & $8,488.9$ & $8,007.5$ & -481.4 \\
2005 & $16,397.5$ & $1,858.7$ & $-14,538.8$ & & & \\
2006 & $17,803.7$ & $2,048.1$ & $-15,755.6$ & & & \\
\hline
\end{tabular}

Sources: Social Security trust fund balances are drawn from The 2007 Annual Report of the Board of Trustees of the Federal Old-Age and Survivors Insurance and Federal Disability Insurance Trust Funds; the estimated underfunding is unpublished data from the Office of the Actuary, U.S. Social Security Administration; private pension plan assets are derived U.S. Pension Benefit Guaranty Board's Pension Insurance Data Book for various years for private defined benefit plans and from the Federal Reserve Bank's Flow of Funds data for various years for defined contribution assets and individual retirement account balances; private pension plan obligations for defined benefit plans also are taken from the Pension Insurance Data Book, and defined contribution plan and individual retirement account obligations were calculated as the equivalent of assets. 
hold described in the preceding, it is clear that their net financial position has deteriorated by $\$ 15,000$ over the year - that is, the growth in total liabilities minus the net increase in cash in hand. One could claim that the household would have been $\$ 5,000$ deeper in debt if it had spent the money rather than putting it in the bank, but it makes no sense to consider the $\$ 5,000$ as savings in the face of the much larger debt it has accrued.

The U.S. Social Security system has had a steadily growing balance in its trust fund accounts over the past two decades, but its underfunding has grown steadily as well. The accumulated funding can be considered saving only to the extent that had the assets not grown, the level of dissaving would have been even higher. The contention by some that accruing Social Security benefits have not reduced workers' other savings would still leave Social Security having a net negative effect on national savings if unfunded obligations are taken into account.

In contrast to Social Security, the private pension system in the United States is largely funded. The private system comprises three elements: employer-sponsored defined benefit plans, employer-sponsored defined contribution plans, and individual retirement accounts. In 1974, the U.S. Congress adopted legislation meant to secure private pensions for workers. For defined benefit plans, these requirements mean that benefits must be funded at roughly the same rate that benefits are earned by participants and that unfunded liabilities must be amortized over a specified schedule. Defined contribution plans and individual retirement accounts are fully funded by the nature of the plans - that is, the obligation of the plan equals its value.

The three right-hand columns of table 8.3 reflect the growing obligations and assets in the U.S. private pension system and correspond with the three columns to their left for Social Security. In this case, private pension obligations in the United States were fully funded on an aggregate basis over most of the period. This does not mean that all defined benefit plans were fully funded; indeed, some were underfunded, but the overfunding in some plans more than offset the underfunding in others. In a national savings context, it is the aggregate balances that are important. In 2002, the system slipped into an underfunded status generally due to declining asset values in the financial markets. In addition, the value of liabilities also increased in defined benefit plans because the interest rates used to calculate full funding requirements fell to historic lows. Some of that underfunding was corrected by a rebound in the financial markets and higher contributions from plan sponsors after 2002.

There has been some chronic underfunding of private defined benefit plans even after the passage of the Employee Retirement Income Security Act (ERISA) in 1974. The Pension Protection Act (PPA) of 2006 has established new funding and disclosure rules for both single-employer and multiemployer pension plans. It increased the funding requirements for singleemployer defined benefit plans generally requiring that sponsors fund 100 
percent of the present value of all benefits accrued as of the beginning of a plan year. Funding shortfalls can be amortized over seven years. In the case of multiemployer plans, the legislation shortens the amortization period for unfunded liabilities to fifteen years and created a condition labeled as "endangered status" where a plan is less than 80 percent funded. Plans in this status are required to file a ten-year funding improvement plan during which they are required to improve their funding status by one-third and to avoid an accumulated funding deficiency.

The funding requirements for private employer pensions are meant to ensure that the plans will generally hold assets at least equal to liabilities. If that goal is not achieved because of fluctuations in either asset or liability values, the system is intended to encourage accelerated saving for assets to catch up to the level of liabilities. Even though unfunded liabilities did increase in the private system toward the end of the period shown in table 8.3 , between 1996 and 2004, private pension assets grew by $\$ 3.5$ trillion, from $\$ 4.5$ trillion to $\$ 8.0$ trillion, while excess funding dropped by $\$ 500$ billion. In other words, from 1996 to 2004, private pensions made net contribution to national wealth of $\$ 3.0$ trillion. At this writing, the Pension Benefit Guaranty Corporation (PBGC) has not yet published the accumulated obligations or funding levels among their insured plans for 2005 and 2006, but the Federal Reserves' Flow of Funds reports suggest that private retirement assets increased another \$1.5 trillion between 2004 and 2006.

The preceding discussion suggests that from 1996 to 2004, aggregate pension saving in Social Security fell $\$ 4.6$ trillion because obligations outstripped asset accumulations significantly, while net private pension savings rose by roughly $\$ 3.0$ trillion because asset growth largely kept up with accruing obligations. Although all economists may not agree on the rate at which pension saving is offset by personal saving, most of them agree there is some offset and some believe it is so substantial that the marginal positive effects on saving are not worth the tax preferences accorded such savings. Still, at the end of the day, no one denies that the accumulated wealth in these plans is savings, whereas most of what is accruing in Social Security is consumer loan obligations.

\subsection{Pension Finance and Savings under Alternative Demographic Scenarios}

We noted earlier that, from the perspective of the worker, the accumulation of pension rights through a pay-go social security system is little different than accumulating wealth through personal savings or a funded pension. The previous section of this discussion suggested that many countries are facing the prospect that their economic performance in coming years will be disappointing to the resident populations and that the pension systems will be used to allocate that disappointment. In that discussion, there was 
no distinction made between countries that have been almost solely reliant on pay-as-you-go retirement systems, such as Germany, Italy, and Sweden, versus those with considerable funding in their retirement systems, such as Canada, the United Kingdom, and the United States, or countries that are attempting to move toward almost full funding of their national retirement systems, such as Australia and Chile.

The demographic composition of a nation's population can affect the potential provision of income for the retiree population under both types of plans. In the case of plans financed on a pay-go basis, the cost of benefit provision is driven directly by the ratio of retirees to workers who finance benefits. As populations age, this "dependency ratio" is expected to rise significantly. In the case of pay-as-you-go retirement systems, if lawmakers determine that the cost of financing the benefits defined in current law is more than workers can bear, they will likely reduce benefits in some fashion, which may put strains on the economic security of people depending on the benefits. In the case of funded plans, the demographic composition of society may also be important. When the baby boomers retire, they will begin to sell off their private retirement assets. The dependency ratio that is important in determining how much pay-go retirement plans cost also defines the relative number of sellers and buyers of assets. We face a future where we will have relatively more domestic sellers of assets compared to buyers than at any time in modern history.

Schieber and Shoven (1997) painted a scenario where the sell-off of baby boomers' defined benefit pension assets has the potential to depress financial market prices, which could put strains on the economic security of people depending on the benefits of pension savings. Specifically, Schieber and Shoven projected private employer contributions to defined benefit plans based on actual contribution rates during the early 1990s and assumed that workers would claim benefits in accordance with benefit formulas then in place when they reached retirement eligibility. Their results suggested that savings in these plans would gradually decline as the baby boomers retired under their base assumptions and turn negative in the mid-2020s. They acknowledged that this scenario was untenable as the trust funds would ultimately run out of assets given the contribution and accrual rates that persisted in private plans in the late 1980s and early 1990s. Still, their results raised the specter that the retirement of the baby boom generation could lead to negative savings.

More recently, James Poterba (2004) has concluded that, aside from the automatic decline in the value of defined benefit pension assets as workers age, other financial assets decline only gradually during retirement. He suggests that when the pattern of asset accumulation and selling by age is used to project asset demands in light of the future age structure of the U.S. population, the results do not suggest a sharp decline in asset demand between 2020 and 2050. Looking at the U.S. situation, however, may be misleading 
because of the relatively favorable demographics that it faces. It might also be misleading because the significant reliance on pay-as-you-go retirement plans significantly reduces the need to cash out assets for many retirees. Full dependence on funded retirement systems would likely change the dynamics of asset decumulation during retirement for many people covered under existing social security pension systems.

In the following discussion, we simulate how pay-as-you-go pensions versus funded pensions would operate under the evolving demographics in three countries with very different population profiles-India, Italy, and the United States. These three countries were chosen because their population profiles are expected to evolve in significantly varied fashions. The simulations help to clarify the importance of demographics on the issues being analyzed.

The model used in this analysis is not a general equilibrium model with built-in feedback and behavioral responses to the evolving economic outcomes under the alternative demographic scenarios. Still, the estimates of economic dependency due to population aging that we model in the various cases link closely with those of other assessments of pay-as-you-go pensions. We are simply applying our estimates of evolving aging dependency to both pay-as-you-go and funded pensions for comparisons in order to show the orders of magnitude of potential swings in important economic variables given a set of demographic scenarios that are tied to population projections associated with actual countries under alternative formulations of retirement systems.

In our modeling of the retirement systems, everyone starts working at age twenty-five and earns $\$ 35,000$ in their first year of employment. There is no inflation. As workers age, they receive a 2 percent pay raise each year until they retire at age sixty-five, 1 percent related to general productivity improvement rates across the economy and 1 percent related to the individual's own productivity associated with experience. Under this set of assumptions, average wages in the economy grow by 1 percent per year. That is, a twenty-five-year-old worker would earn 1 percent more in 2006 than a similarly situated worker earned in 2005 and so on. We assumed that workers would earn average wages for their cohort and that all working-age citizens would work full time until death or retirement at age sixty-five. This latter assumption, while not very realistic, will not bias the analytical results as long as a relatively constant proportion of each working-age group is actually employed over time. We assumed that life expectancy was equivalent to rates that persisted in the United States in 2000 as estimated by the U.S. Social Security actuaries.

The example assumes that workers' annual contributions to their pension are 13.9 percent of pay over their forty-year careers and that those assets accrue annual returns of 4 percent. Retirees receive benefits worth 70 percent of their final earnings. Some analysts contend that this level of 
Quasi-retirement income replacement rates for selected countries (\%)

\begin{tabular}{|c|c|c|c|c|}
\hline \multirow[b]{3}{*}{ Country } & \multicolumn{4}{|c|}{$\begin{array}{l}\text { Percentage of mean disposable income of } \\
\text { people ages } 65-74 \text { compared to: }\end{array}$} \\
\hline & \multicolumn{2}{|c|}{ People aged 51-64 } & \multicolumn{2}{|c|}{ People aged $41-50$} \\
\hline & Mid-1980s & Mid-1990s & Mid-1980s & Mid-1990s \\
\hline Canada & 82.4 & 86.9 & 78.2 & 86.6 \\
\hline Finland & 77.6 & 75.5 & 69.2 & 71.6 \\
\hline Germany & 78.1 & 84.4 & 75.5 & 78.2 \\
\hline Italy & 76.4 & 78.7 & 77.8 & 78.1 \\
\hline Japan & 82.3 & 79.6 & 84.8 & 81.8 \\
\hline The Netherlands & 83.1 & 80.7 & 85.2 & 78.9 \\
\hline Sweden & 76.1 & 76.1 & 73.6 & 80.3 \\
\hline United Kingdom & 70.4 & 74.1 & 59.9 & 65.0 \\
\hline United States & 82.2 & 79.9 & 84.3 & 83.6 \\
\hline
\end{tabular}

Source: OECD $(2001,22)$.

retirement income exceeds the level needed for many individuals to maintain their preretirement standard of living, but it is not inconsistent with the level of income realized by retirement-age populations across many of the developed economies of the world as shown in table 8.4. The table shows mean disposable income of people ages sixty-five to seventy-four, people who would be largely retired in most developed countries, relative to mean disposable income of people at younger, working ages.

India, Italy, and the United States had highly varied demographic profiles over the past half century. The total fertility rate in India in 1950 was around 6.0 but has declined steadily to around 2.5 in 2000. The United States was in the early part of its postwar baby boom in 1950, but by the late $1960 \mathrm{~s}$, the total fertility rate had dropped to under 2.0 , where it hovered for several years before rebounding to around the 2.1 replacement rate toward the end of the century. Italy did not have a significant postwar baby boom, and its total fertility rate dropped from around 2.5 in the mid $1960 \mathrm{~s}$ to about half that by 2000 . In the simulations we are doing here, workers begin their careers at age twenty-five and work steadily until retiring at age sixty-five. These variations in past fertility rates will play a significant role in determining the relative size of the working and retiree populations for decades to come.

The cost of a pay-as-you-go pension is simply the product of the retiree dependency ratio - the ratio of retirees to workers - and the ratio of average pension benefits to average wages of workers. For the three countries under study, dependency ratios are projected to increase significantly (figure 8.3). Despite the fact that we used a U.S. 2003 period life table in developing these simulations, the dependency ratios we project here are in relatively 


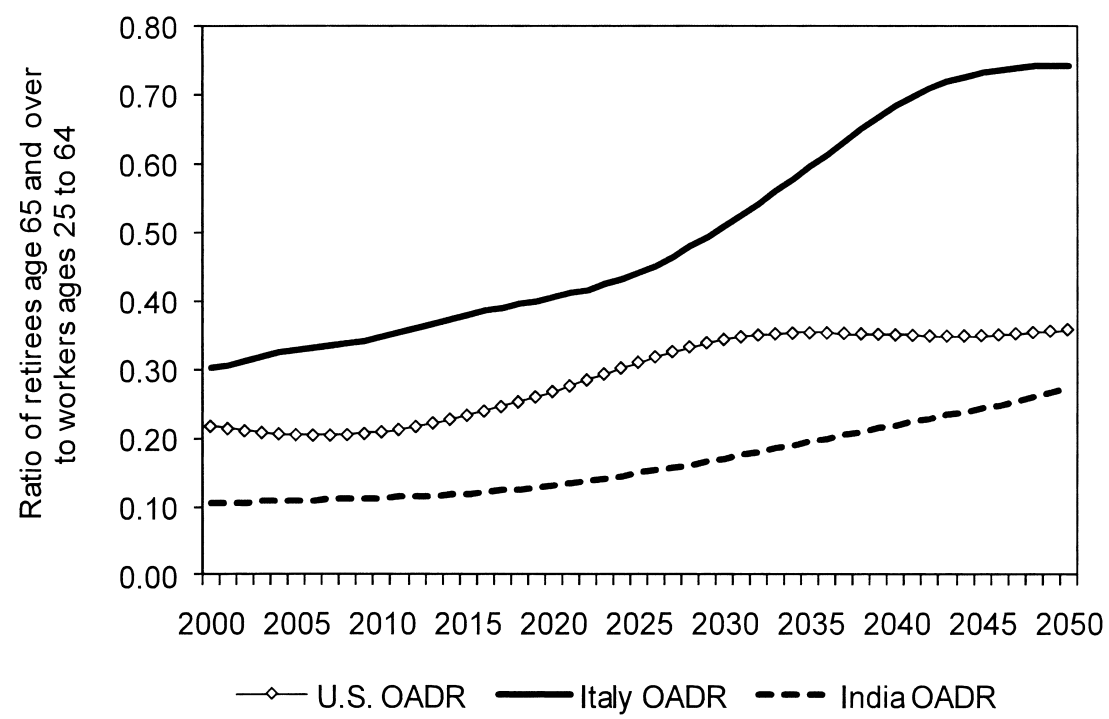

Fig. 8.3 Simulated retiree dependency ratios for India, Italy, and the United States Source: Derived by the author.

close alignment with the United Nations (UN) population projection of the relative size of the working-age population, ages twenty to sixty-four, to the retirement-age populations in the three countries for 2030. Using the UN World Population Prospects 2000 revision for our baseline population estimates, we estimated an aged dependency ratio for Italy of 0.506 in 2030, of 0.157 for India, and 0.365 for the United States (Nyce and Schieber 2005, 70).

In our simulated model, retirees' benefits will always be 70 percent of workers' average wages in the year before they retire. People start working at age twenty-five and retire at age sixty-five. In a pay-as-you-go system, variations in the cost of total benefits over time will be driven purely by the dependency ratio. This is a reasonable characterization of a typical national retirement pay-as-you-go retirement system. The cost of a pay-as-you-go retirement system financed by taxing workers' earnings can be reflected as the ratio of total benefits paid to retirees relative to workers' total wages. That ratio approximates the payroll tax required to support system.

In developing any set of projections of population composition, certain assumptions are required. We used fertility and immigration assumptions from the UN World Population Prospects 2000 revision in developing our projections. In subsequent revisions, both fertility and immigration assumptions have been increased under the UN's projections. Between 2005 and 2050 , the $2006 \mathrm{UN}$ estimated total fertility rate in Italy is ranges between 7 and 15 percent higher than estimated in 2000. Immigration rates for Italy in 
the UN's 2006 estimates are generally more than double the rates estimated in 2000. For the purposes of this exercise, the immigration assumptions are more important over much of the period than fertility rates in projecting aged dependency. By definition, aged dependency is the number of retirees divided by the working population. Increases in fertility today will not affect the number of workers for another twenty years or so. Higher immigration, which tends to be concentrated among younger working-age individuals, on the other hand, can have an immediate effect on aged dependency rates. Using the $2006 \mathrm{UN}$ demographic projections, the number of people in Italy over the age of sixty-five divided by the number ages twenty to fifty-nine results in a ratio of 0.73 in 2030 . By comparison, the 2000 projections yield a ratio of 0.78 . This difference may be significant in a statistical context but would only raise the Italian pay-as-you-go pension cost projections by 3 to 4 percentage points in 2030. For other reasons, discussed in the following, we have reason to believe our projections of aged dependency and pension costs may already be low compared to other estimates, so we do not believe changing the assumptions would significantly alter the conclusions derived here. For the longer term, fertility assumptions become very important, and we believe the assumption that assumptions that Italy's fertility rate will increase markedly relative to recent history without a rationale for it doing so is questionable in making projections of this sort.

Figure 8.4 shows the estimated payroll tax rates that would be required to support future benefit payouts from our hypothetical pay-as-you-go systems in India, Italy, and the United States under our assumptions and demographic projections. The direct linkage between the dependency ratios and the cost of benefits in these systems is clear. There is a highly correlated

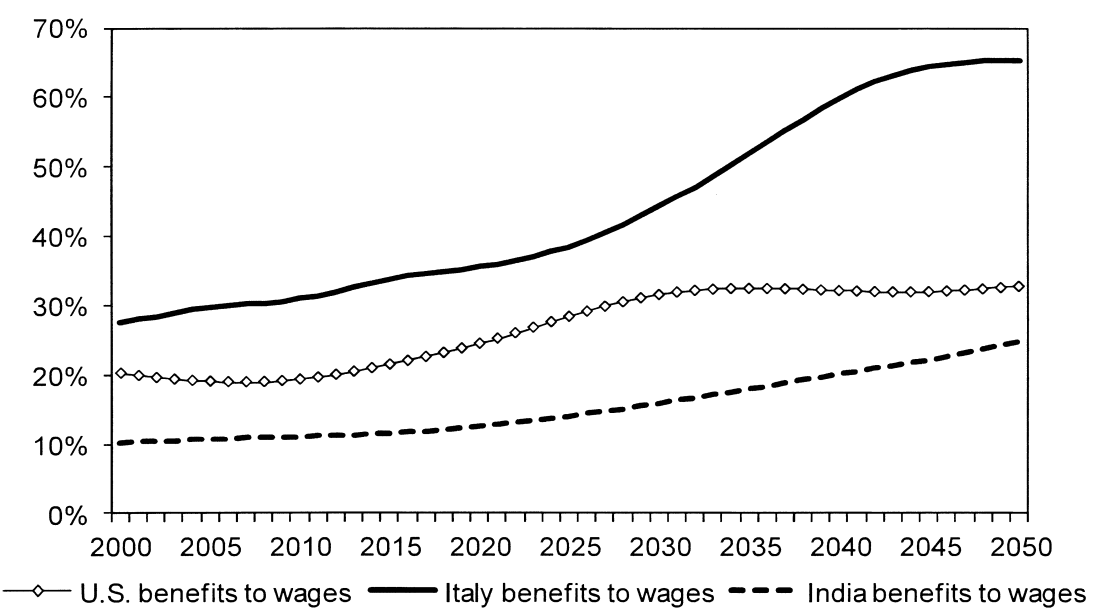

Fig. 8.4 Simulated pension payroll tax rates for India, Italy, and the United States Source: Developed by the author. 
correspondence between the dependency distributions in figure 8.4 and the cost distributions in figure 8.4. The Indian and, potentially, the U.S. scenarios could conceivably be supportable in many developed countries. Yet in the U.S. case, the rapid run-up in tax rates between 2010 and 2030 to support a pay-go financed program could create significant burdens on workers as the full benefit of their improving productivity is siphoned off to support the growing retiree population due to rising pension and health costs (Schieber 2008). The Italian scenario, however, would appear to be unsupportable in any event, which is why a number of countries, including Italy, have embarked on pension reforms. In many cases, an element of the pension reform has been a shift in the direction of funding pension obligations.

Given Italy's demographics, the problem with its pay-as-you-go pension system is that workers likely would be neither able nor willing to support it. In most developed countries, older people vote at much higher rates than younger ones, which could inspire policymakers to protect their interests. However, in Italy and some other countries, the costs of these systems would become so burdensome that workers likely would not pay them. Workers could choose to work outside the formal economy, scale back their work efforts, or immigrate to an economy with more tolerable tax burdens.

The simplifying assumptions used in developing these projections give rise to the question of whether the cost projections presented in figure 8.4 are reasonable. Börsch-Supan, Köke, and Winter (2005) have simulated the cost of pay-as-you-go pension systems in France, Germany, and Italy through 2030 and estimate that the cost of the Italian system would be 62 percent of the national wage bill that year compared to the estimate of 44 percent presented in figure 8.4. This suggests our results are conservative compared to projections that others are presenting.

The Italian system would be more expensive than estimated here under a projection of its recent historical operations because labor force participation rates among the adult population are significantly lower than in our simulations and because most workers in Italy retire much earlier than we have simulated. Given recent age-gender labor force participation rates, Nyce and Schieber $(2005,63)$ estimate that the Italian dependency ratio of retirees to active workers in 2030 will be about twice the level estimated in the simulations presented in figure 8.3. The cost of the actual pension system in Italy would be ameliorated somewhat relative to the simulation result presented in figure 8.4 because our simulations are based on a benefit that is larger relative to preretirement earnings than the Italian system provides.

A funded pension may not fully ameliorate the adverse economic effects of demographics like those in Italy. As noted earlier, pensions are simply devices retirees use to make a claim on the goods and services available in the economy. In a funded pension, retirees claim their share of these goods and services by selling off assets they accumulated during their careers to work- 


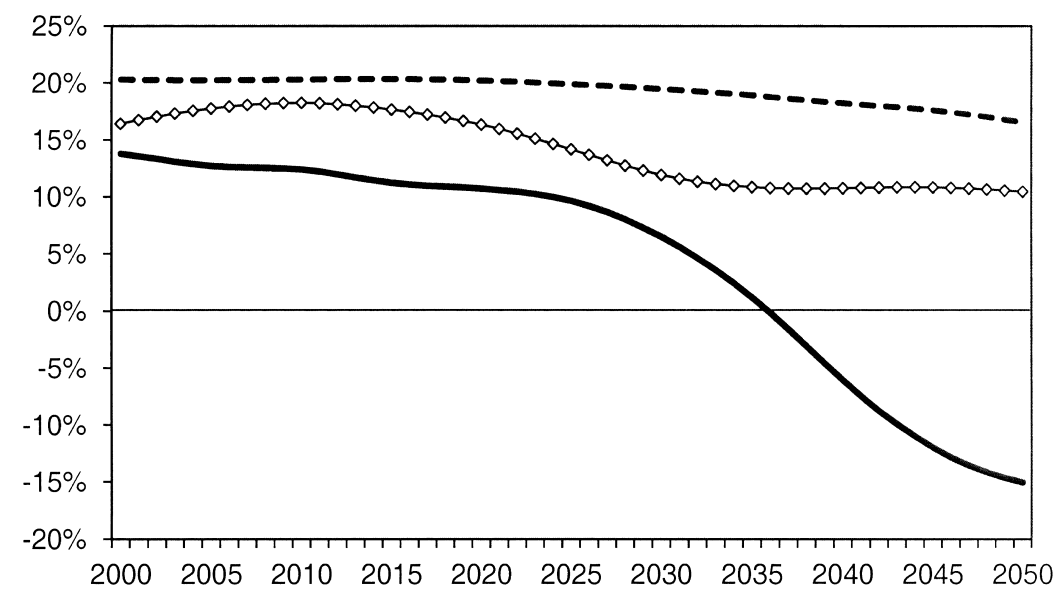

Fig. 8.5 Simulated savings rates through a funded pension system for India, Italy, and the United States assuming work begins at age 25 and retirement at age 65 Source: Developed by the author.

ers. In simulating the funded version of the pension systems in this analysis, we assumed that workers had been covered by a funded pension over their entire careers. In this scenario, if too many assets were sold too quickly, it would portend the collapse of asset values.

Figure 8.5 illustrates the implications of alternative demographic outlooks by showing the contributions that funded pensions would make to national savings. The national savings rate in the simulation results presented here is the amount of workers' pension contributions - which would be 13.9 percent of their pay - plus the interest income on assets, minus benefit payouts. National income is the sum of all wages paid to workers plus the sum of all interest paid on savings. The national savings rate is the aggregate of savings divided by total income.

In the United States, the contribution to national savings from a funded pension system under the simulations would peak at about 18 percent around 2010 and then gradually decline thereafter. This corresponds with the anticipated retirement of the baby boom generation in the United States. The deterioration of savings rates from the simulation would settle out by roughly 2035 at just over 10 percent. However, savings rates continue to decline at a more gradual pace reflecting the persistently low rates of fertility anticipated over the coming decades. All in all, even under a funded pension system, the United States could see its national savings rate associated with a fully funded pension system cut in roughly half from their peak by the mid-2030s.

As significant as the shift in potential savings rates might appear in the United States, the shift would be far more pronounced in Italy, which is 
already approaching the demographic conditions that the United States will face a quarter century from now. Over the next fifteen years or so, the last large cohorts of working-age people will pass over the retirement age used in these simulations. At that juncture, the long-term implications of extremely low fertility rates would take their toll even on a funded pension system. By roughly 2035, a fully funded pension system in Italy would no longer be adding to national savings. And by 2050, the sell-off of assets would be equivalent to 15 percent of national income.

Figure 8.6 shows the estimated pattern of savings in France, Germany, Italy, and the Netherlands, where savings at each age are stated as a percentage of the savings held by forty-year-olds. In explaining the differences across the various countries, Börsch-Supan, Köke, and Winter (2005) focus on the differences in the pension plans that operated in the various countries. In the Netherlands, the declining levels of savings at higher ages reflects the draw-down of their funded pensions. If reliance on funded pensions at the individual level results in savings rates declining and even turning negative at advanced ages, then it would seem extremely high aged dependency could lead to negative savings rates in the aggregate at some point.

In terms of aggregate savings rates, the pattern of saving in Germany that Börsch-Supan (2004) projected under their pre-2002 pension reforms is shown in figure 8.7. These results were for a closed economy projection, which corresponds with the nature of the projection in figure 8.5, although his open-economy projections are not all that different. While Borsch-Supan projects a significant decline in the German national savings rate related to their population aging, it is not nearly the magnitude that we are projecting here. The relative structure of the retirement systems may be an important

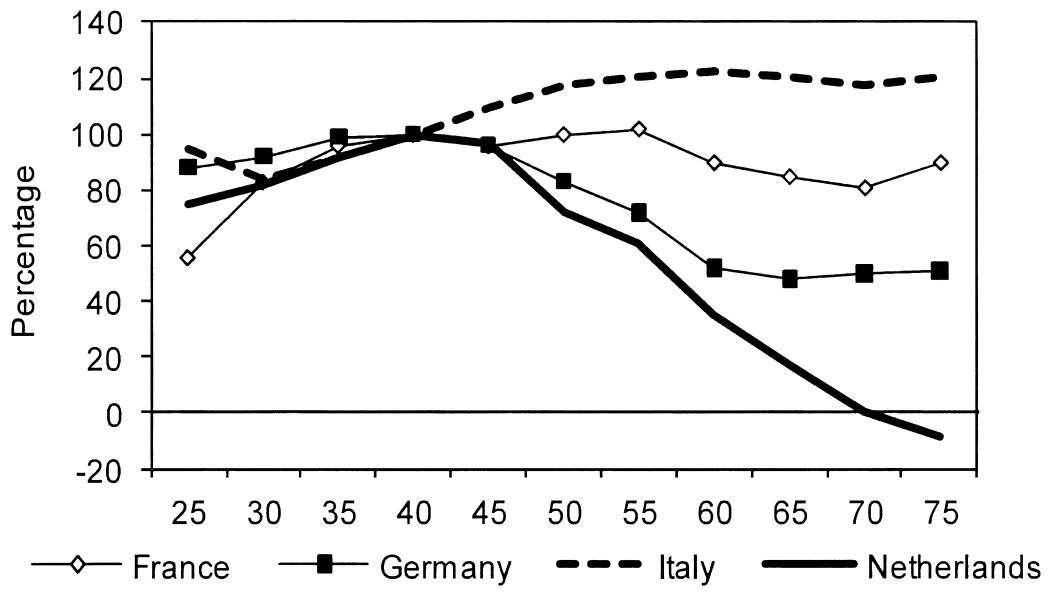

Fig. 8.6 Cohort-corrected savings rates by age for various countries Source: Börsch-Supan, Köke, and Winter $(2005,95)$. 


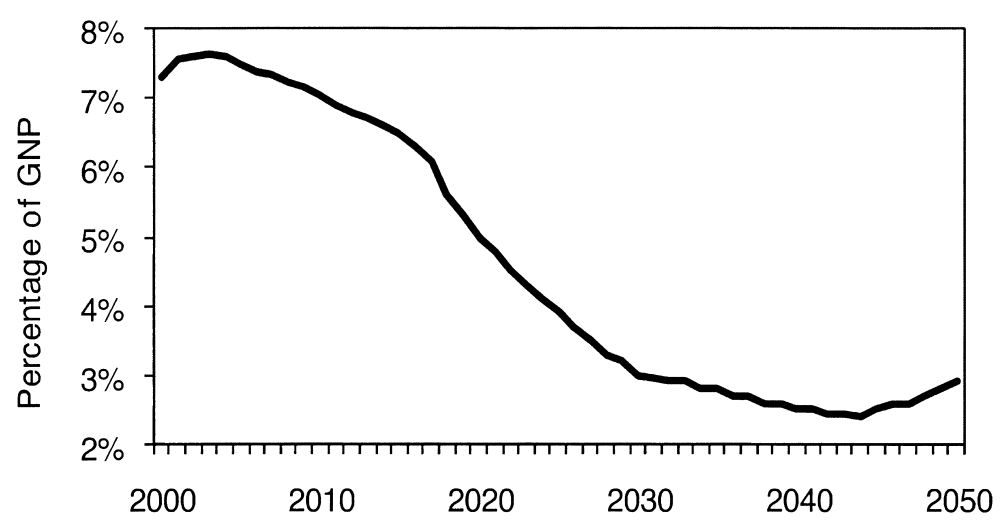

Fig. 8.7 Projections of the German aggregate savings rate under their pre-2002 pension system

Source: Börsch-Supan $(2004,33)$.

consideration here. Börsch-Supan, Köke, and Winter $(2005,93)$ estimate that funded pensions systems in France, Germany, and Italy comprised 5 percent or less of household wealth in 2000 compared to 38 percent in the Netherlands, 22 percent in the United Kingdom, and 24 percent in the United States.

Yet in Germany and other countries with large public pension systems, there was considerable private saving going on in recent decades. If their pension systems had been funded, added savings outside the pension systems would likely have also been the norm. Would the Germans have saved outside a funded pension system at comparable levels they saved outside their pay-as-you-go system? Even if they did, the net swing in the German savings rate would be much larger than that shown in figure 8.7 because the direct saving and dissaving related to the retirement system would overlay other saving, positively affecting the rate during the positive demographic period and negatively affecting it during the period of high aged dependency.

The point here is that demographic conditions in some nations could result in economic chaos unless retirement patterns change radically, regardless of how retirement systems are organized and financed. It is unlikely that payroll tax rates of over 60 percent, or even 50 percent, are sustainable - yet current projections suggest some countries would have to increase taxes to these levels to support their pay-as-you-go retirement systems. The alternative - trying to weather the demographic storm with a funded pension system - may not be much better. But the funded pension plan offers one safety valve that the pay-as-you-go plan does not from a macroeconomic perspective. The assets accumulated in a funded pension can be invested in other economies around the world and can allow a nation to diversify its 
demographic risks accordingly. Indeed, the prospect of increased savings related to the move toward funded pensions in a number of aging countries will face declining demand for capital where workforces are not only aging but shrinking.

Countries like Canada, Germany, and Sweden have adopted new pension policies in recent years with the intention of increasing the funding of accruing pension obligations with an eye toward increased investing of pension assets in foreign markets. But in many countries, there are still biases toward investing close to home and political resistance to use foreign capital markets to help ameliorate the longer-term implications of population aging. An editorial in the Washington Post (Myerson 2004, A19) a while back made the case that the burden of proof was on policymakers "to demonstrate how private investment in a global economy creates jobs here at home. And why the hell our tax policy should boost income in Bangalore, not Baltimore."

Shifting to a funded retirement system without also adopting incentives to boost workforce participation could ultimately lead to large declines in national savings rates or even to negative savings rates in some developed economies. Even if these economies do not collapse under the crushing pressure of aged dependency, the resources needed to support publicly financed pensions will put tremendous strain on all other facets of government expenditures.

\subsection{Economic Operations and Limitations in Aging Societies}

Under assumptions that the economies discussed in the preceding section were closed to foreign trade and exchange, the operations of pay-as-you-go versus funded pensions for individual workers, as summarized in table 8.1, would aggregate up for the total economy. Focusing on the Italian case, the high rates of payroll taxes under the pay-as-you-go pension scenario almost certainly would lead to reduced standards of living for those working and their dependents. But the rates of asset sales implied in the funded pension scenario would require workers to save outside of their retirement saving at such high rates that their consumption rates would almost certainly have to fall relative to levels achieved by earlier cohorts of workers. Any alternative that would allow working-age people to save less and to increase their standards of living would suggest significant reductions in living standards for retirees because the value of their savings would be reduced. The pension system, then, will be the fulcrum for allocating the economic disappointment.

The rate of growth of gross domestic product (GDP) in an economy is the sum of labor force growth and the growth in worker productivity. For the United States, the decade-by-decade levels of real output (GDP), total labor supply (billions of hours), and productivity (GDP per hour) measures are shown in table 8.5 from 1950 through 2006. The growth rates in the table are the decade-by-decade compound annual growth rates, except for the 2000s, 
where they reflect the first six years of the decade and were derived from the base data. The GDP growth rates shown in the table vary slightly from the sum of the growth rates in the labor supply and productivity measures due to rounding of the various base measures. While it is not shown in the table, the combination of a growing labor force and improving worker productivity has resulted in a steady increase in standards of living in the United States as measured by per capita GDP.

The labor force growth rates shown in table 8.6 and those in any economy depend on the demographics of the society and the labor force behavior of the working-age individuals in it. There are a variety of factors that contribute to worker productivity improvement rates. To a considerable extent,

Levels and growth rates in U.S. gross domestic product (GDP), total labor supply, and output per hour

\begin{tabular}{|c|c|c|c|c|c|c|}
\hline \multirow[b]{2}{*}{ Year } & \multirow{2}{*}{$\begin{array}{c}\text { GDP } \\
\text { (in billions } \\
\text { of } 2000 \$ \text { ) }\end{array}$} & \multirow{2}{*}{$\begin{array}{l}\text { Labor supply } \\
\text { (billions of } \\
\text { hours worked) }\end{array}$} & \multicolumn{4}{|c|}{$\begin{array}{l}\text { Compound annual growth rate from } \\
\text { prior to current year in: }\end{array}$} \\
\hline & & & $\begin{array}{l}\text { GDP per } \\
\text { hour }(\$)\end{array}$ & $\begin{array}{c}\text { GDP } \\
(\%)\end{array}$ & $\begin{array}{c}\text { Labor } \\
\text { supply }(\%)\end{array}$ & $\begin{array}{l}\text { GDP per } \\
\text { hour }(\%)\end{array}$ \\
\hline 1950 & $1,777.3$ & 122.4 & 14.5 & & & \\
\hline 1960 & $2,501.8$ & 134.6 & 18.6 & 3.48 & 0.95 & 2.50 \\
\hline 1970 & $3,771.9$ & 157.3 & 24.0 & 4.19 & 1.57 & 2.58 \\
\hline 1980 & $5,161.7$ & 185.0 & 27.9 & 3.19 & 1.63 & 1.53 \\
\hline 1990 & $7,112.5$ & 219.9 & 32.3 & 3.26 & 1.75 & 1.48 \\
\hline 2000 & $9,817.0$ & 257.9 & 38.1 & 3.28 & 1.60 & 1.64 \\
\hline 2006 & $11,319.5$ & 261.7 & 43.3 & 1.43 & 0.15 & 1.29 \\
\hline
\end{tabular}

Source: Office of the Chief Actuary, U.S. Social Security Administration.

Table 8.6 Compound annual growth in gross domestic product per capita for various Organization for Economic Co-operation and Development countries over selected decades

\begin{tabular}{lcccc}
\hline Country & $1960 \mathrm{~s}$ & $1970 \mathrm{~s}$ & $1980 \mathrm{~s}$ & $1990 \mathrm{~s}$ \\
\hline Austria & 4.05 & 3.54 & 2.07 & 1.74 \\
Canada & 3.07 & 3.04 & 1.56 & 1.64 \\
France & 4.47 & 2.66 & 1.84 & 1.34 \\
Germany & 3.71 & 2.70 & 2.10 & 2.33 \\
Italy & 4.97 & 3.10 & 2.16 & 1.44 \\
Japan & 9.01 & 3.25 & 3.51 & 1.07 \\
The Netherlands & 3.74 & 2.08 & 1.62 & 2.31 \\
Sweden & 3.91 & 1.60 & 1.87 & 1.39 \\
Switzerland & 3.23 & 1.19 & 1.54 & 0.18 \\
United Kingdom & 2.29 & 1.81 & 2.47 & 1.88 \\
United States & 2.92 & 2.25 & 2.16 & 2.25 \\
\hline
\end{tabular}

Source: Nyce and Schieber $(2005,165)$. 
they are dependent on the other factors of production - the level of capital stock that workers utilize in their jobs and the level of technology imbedded in it. In addition, they are also dependent on the innate abilities of the workers themselves - their health status, education levels, and possibly their age. The latter may be more important in some types of work than others. Rates of productivity improvement also depend on labor practices. Finally, managerial practices, how work is structured, workers compensated, and the like are important.

In an historical context, the combination of labor productivity improvements and labor force growth have resulted in steady decade-to-decade economic growth and rising standards of living in all the economies of the developed world. The rates vary somewhat from decade to decade and from country to country, but GDP per capita consistently increased across the last four decades in all developed nations, as reflected in table 8.6.

Long-term patterns of the sort reflected in table 8.6 tend to create expectations of further improvements in living standards. Most people hope for increasing prosperity, if not for themselves, then for their children and grandchildren. And certainly most young adults aspire to improve their lot. Improving the status of generations across time typically implies economic expansion. So while most people may aspire to increasing output per capita, that may become increasingly difficult to achieve given the demographic developments ahead.

The history of labor force growth that has persisted over virtually the whole period since the beginning of the industrial revolution in what we consider today to be the highly developed economies of the world is likely to be reversed in the relatively near future. Assuming that people continue to conform to the working patterns of recent years, the aging populations may create workforce contractions in several countries during this decade or next. Börsch-Supan (2004) has estimated that the German labor force will contract from 36 million workers in 2010 to around 32 million by 2025 . Clark, Ogawa, and Matsukura (2008, 3) estimate that the Japanese labor force peaked at 67.9 million workers in 1998 and dropped to 66.4 million workers in 2004. They conclude that "if age specific labor force participation rates remain constant, the labor force will reflect the smaller, older population and the rate of decline in the labor force will tend to exceed the rate of decline of the population." They estimate that the labor force could decline by 2.2 percent between 2005 and 2010 and another 7.1 percent between 2010 and 2020 (Clark, Ogawa, and Matsukura 2008, table 5). Given the age structures and normal life expectancies in the developed countries, where labor forces are expected to contract, they are likely to do so prior to the contraction of national populations. This may be occurring in Italy, Japan, Sweden, and Switzerland this decade and accelerate in the next, while also spreading across a number of other countries as well.

Assuming that recent age-gender employment levels would persist into the 
future, Nyce and Schieber (2005) estimated that in the 2010s, roughly two out of every three developed countries will experience a reduction in labor supply under projections using recent demographics and labor force participation patterns. Even in Australia, Ireland, and the United States, which are expected to have relatively persistent labor force growth in the coming years, labor supply growth rates during the 2010s will be half to one-quarter those of the 1990s (Nyce and Schieber 2005, 183). Employers in the developed countries may face considerable challenges in finding sufficient numbers of talented employees to run their operations. If labor force growth rates slow to the levels anticipated in some of these countries, the result could be economic stagnation or even economic decline, depending on the severity of the workforce contraction.

If population aging leads to slower or negative growth of labor supplies in the developed economies and that slows economic growth, declines in rates of improvement in living standards will follow. This would not necessarily occur if total population growth were slowing to the same rate as labor force growth or contracting in the cases where the labor force will be getting smaller. But the populations in virtually all of these countries will not begin to contract for some time due to their evolving demographic structures. The problem is that labor force contraction due to increasing numbers of retirees associated with aging populations precedes population decline. The standard of living is determined by the distribution of output across the whole population. If the rate of improvement in living standards is slowed due to the demographic transition underway, then the loaded question many societies will have to answer is who will bear the brunt of the slowdown. The character of the retirement systems in many countries will likely have a lot to do with how they answer that question.

In order to demonstrate the implications of the changing demographics in developed countries, Nyce and Schieber (2005) projected the levels of output in the developed economies of the world on the basis of assumptions that labor productivity improvement rates achieved in recent years would persist in the future and that labor force participation patterns by age and gender of the working age population at the beginning of the century would persist over the next couple of decades. In this manner, it is possible to estimate how changing demographics would alter economic performance for countries dependent upon their own domestic capacity. The results suggest that population aging would lead to a slowdown in the historical growth rates in standards of living. This was especially the case in the 2010 s projection series. If this outcome is ultimately realized, then the question the developed societies face is who bears the brunt of the slowdown in improving living standards. The answer to this question: it depends on pension policy.

In many countries, retirement benefit levels are tied to workers' productivity levels through some form of wage indexing. Even where pension benefits are tied to general growth in income levels or to price indexing, the dispro- 
portionate growth in the cost of health benefits consumed by retirees tends to increase the cost of total retiree benefits at rates approaching those of wages. If retirees largely depend on pensions that grow with worker productivity or wages, pension systems will insulate retirees from the slowing economic growth resulting from population aging and slower labor force growth. As retirees become a larger share of the population, they potentially could divert more of the benefits of productivity growth - meaning higher standards of living - from the active workforce. This would place a growing real burden on workers and their dependents.

In order to show the implications of slower economic growth resulting from population aging and to show the potential from alternative policies for dealing with it, Nyce and Schieber (2005) considered two scenarios for how policymakers might allocate the economic disappointment of slowing improvement in standards of living. In the first scenario, they assumed that retirees would receive pensions that grow at the rate of growth in wages. After retirees received their share of the national output on this basis, the residual improvement in workers' living standards were estimated from distributing what would be left in national output. In the second scenario, the allocation process was reversed: workers were assumed to benefit fully from their improving productivity, and the residual was then divided among the retiree population.

The results of the simulations for the 2010s from the first scenario simulation are presented in table 8.7 for a selected set of countries. The results suggest that workers could end up seeing their incomes grow significantly slower than their productivity improvement rates if existing pension policies

Table 8.7 Annual growth in workers' per capita income levels assuming the elderly population's income grows at the rate of growth in worker productivity

\begin{tabular}{lcc}
\hline & \multicolumn{2}{c}{$2010-2020$} \\
\cline { 2 - 3 } Country & $\begin{array}{c}\text { Worker productivity } \\
\text { improvement rate }\end{array}$ & $\begin{array}{c}\text { Growth rate in workers' } \\
\text { per capita income }\end{array}$ \\
\hline Australia & 2.05 & 1.61 \\
Canada & 1.50 & 0.87 \\
Denmark & 2.07 & 1.70 \\
France & 1.23 & 0.63 \\
Germany & 1.49 & 0.95 \\
Italy & 1.54 & 1.00 \\
Japan & 1.12 & 0.76 \\
Spain & 1.31 & 0.88 \\
Sweden & 2.49 & 2.24 \\
Switzerland & 0.65 & 0.12 \\
United Kingdom & 1.93 & 1.48 \\
United States & 1.48 & 1.10 \\
\hline
\end{tabular}

Source: Nyce and Schieber $(2005,189)$. 
in many countries are carried forward despite population aging. In interpreting the results of the table, it is important to keep in mind that the results show a marginal loss of income relative to productivity improvement over and above whatever level of taxes workers are already bearing.

In the abstract, the allocation of output along the lines suggested in table 8.7 is no better or worse than any other suggested distribution of output. The potential issue likely to arise, however, is that with the slowdown in growth or even shrinkage of the labor supply, the primary factor driving economic growth will be improving worker productivity. Workers may be less than enthusiastic about increasing their levels of output when they are losing ground in their own living standards relative to those who have withdrawn from the workforce.

The eventual situation in many countries may be much worse than the scenario depicted in table 8.7 suggests because the results of the analysis presented here focus only on added pension claims related to population aging and extra health claims may add as much or more cost related to population aging than pension costs (Costello and Bains 2001; Nyce and Schieber 2005). The disincentives that high taxes on labor create are a concern-workers simply are not willing to work harder indefinitely if they are not rewarded for their efforts. If we lose the benefits of continued improvement in worker productivity levels, the implications of population aging could become even direr than suggested here.

Several countries have already taken actions or proposed ways to limit the liabilities that pension systems will place on workers. In the United States, President George W. Bush suggested that the indexing of initial Social Security pensions might not be directly linked to average wage growth in the future for all workers. Several other countries, including Germany, Italy, Japan, and Sweden have already adopted a range of measures to restrict the growth of their retirement systems.

To the extent that policymakers limit the implications of population aging on pension costs, it will protect workers, at least partially, from the demographic transition that is underway. Insulating workers from the economic implications of changing demographics, however, has the potential to adversely affect standards of living for the elderly, probably through erosion in their benefits. To see the implications of this scenario, consider the results presented in table 8 . Here, workers and their dependents are assumed to realize improvements in their consumption rates consistent with improving productivity, and that the residual of total output would be allocated to retirees. In this case, the news is contained in the right-hand column of table 8.8. Where the entry has a negative sign, it suggests that standards of living among the elderly will be falling.

The results suggest that if policymakers respond to population aging by simply driving down the income levels of the elderly, there could be significant declines in standards of living among the elderly across much of 
Table 8.8

Annual growth in per capita income levels for the elderly population assuming workers' income increases at the rate of increase in productivity with the residual

\begin{tabular}{lcc}
\hline & \multicolumn{2}{c}{$2010-2020$} \\
\cline { 2 - 3 } Country & $\begin{array}{c}\text { Worker productivity } \\
\text { improvement rate }\end{array}$ & $\begin{array}{c}\text { Growth rate in retirees' } \\
\text { per capita income }\end{array}$ \\
\hline Australia & 2.05 & -0.12 \\
Canada & 1.50 & -1.28 \\
France & 1.23 & -0.82 \\
Germany & 1.49 & -0.38 \\
Italy & 1.54 & -0.05 \\
Japan & 1.12 & -0.30 \\
Spain & 1.31 & -0.50 \\
Sweden & 2.49 & 1.11 \\
Switzerland & 0.65 & -1.65 \\
United Kingdom & 1.93 & 0.31 \\
United States & 1.48 & -1.05 \\
\hline
\end{tabular}

Source: Nyce and Scheiber $(2005,191)$.

the developed world over the next decade. The phenomenon could become widespread. The prospect of solving the aging challenge by pushing more and more elderly into substandard income levels is likely to be regarded as unacceptable by many policymakers. The significant benefit adjustments to pension systems that have already been adopted in a number of countries suggest that this scenario may actually be embedded in current policy in a number of cases.

\subsection{Can Pension Funding Trump Population Aging?}

Earlier we raised the question of whether it made much difference whether a country facing a demographic situation similar to Italy's had a pay-as-yougo or funded retirement system. Ultimately, it may not, but it is likely that a funded pension system would offer countries facing dramatic increases in their aged dependency levels more options for dealing with its demographic outlook than a pay-as-you-go system. A funded pension system might relieve some of the pressures associated with population aging due to the fact that such systems have to adjust to market conditions more rapidly than politically directed pay-as-you-go systems. To the extent that aging would lead to significant sales of assets under a funded pension system, asset prices could decline and diminish the proceeds being paid to the owners, prompting them to work longer to make up for the loss in retirement savings value.

In this regard, it is possible that the organization of funded pension sys- 
tems will play a significant role in how quickly they respond to demographic pressures. A system organized like the Canadian national defined benefit plan, where a portion of the benefit obligation is being funded but the benefit structure is still defined by legislative fiat, may not be as responsive to excess benefit claims as the Australian system that is essentially organized as a capital accumulation device with actual benefit payout being determined at the point an individual worker retires. In the former case, it is possible that political pressure will allow funding ratios to be depleted while corrective legislation is considered. In the latter case, the ruthless arithmetic of life expectancy and available resources to support it will dictate benefit adjustments in real time.

Potentially, the greatest advantage that funded pensions offer is to give countries an option to tap outside productivity by investing in global financial markets that a pay-as-you-go system cannot. While capital flows have increased in recent years, there is still reason to be concerned about home bias in investing patterns including the investment of pension assets that will reduce the effectiveness of pension funding as a mechanism for dealing with population aging. If Italy and other developed countries had funded their national pensions as they were maturing and invested in other economies around the world with an eye toward future labor availability, the sell-off of significant pension assets due to population aging would be relatively inconsequential for the home economy.

If a country needs to augment the productivity of its workforce to generate sufficient output for its society, the ability to do so with a traditional pay-as-you-go financing scheme is extremely limited. Funded pensions, on the other hand, have significant potential in allowing countries to diversify their demographic risks because capital can move across borders relatively freely. The returns on capital invested outside of the owner's home country create the prospect of tapping the productivity of foreign labor that is otherwise hard to achieve.

In the final analysis, however, countries do not face an instantaneous choice between funded or pay-as-you-go retirement systems. Those that are largely dependent on pay-as-you-go financing face the prospect of higher taxes or lower benefits as they work out the allocation of the economic disappointment they are facing. They may buffer the longer-term ramifications of prior policies by moving toward greater funding of future pension promises, but someone has to bear the burden of the outstanding consumer loans. If the workers are given the burden, they pay twice - once to cover the old payas-you-go obligations at the same time they bear the cost of prefunding their own retirement income claims. If the retirees are given the burden, they end up with less income in retirement than they expected when they paid their part of the consumer loan bargain. Any transition from a pay-as-you-go pension system to a funded one is necessarily a long-term undertaking that 
involves substantial cash-flow support while it is underway. Accomplishing such a transition at the point that aged dependency is already challenging general economic prosperity is likely to be doubly daunting.

In the German case, policymakers tried to split the hair. They put a limit on the payroll tax claim they would allow the national retirement plan to make, which meant some reduction in pension benefits for current retirees that will increase over time and gave workers tax incentives to save to make up for the implicit reductions in benefits that follow. From the perspective of making claims on foreign workers, it is going to be a long time before there are sufficient assets in Germany's added pension funding to provide any significant buffer for the excessive levels of aged dependency that they face now and over the next couple of decades. It is likely that a key component of the answer to the aging challenge that Germany and most developed countries face today is to increase the numbers of workers in their domestic economies. That almost certainly means that workers will have to remain employed later in life than was generally the case at the end of the twentieth century.

\section{References}

Börsch-Supan, Axel. 2004. Global aging, issues, answers, more questions. University of Michigan Retirement Research Center, Working Paper no. 2004-084.

Börsch-Supan, Axel, F. Jens Köke, and Joachim K. Winter. 2005. Pension reform, savings behavior, and capital market performance. Journal of Pension Economics and Finance 4:87-107.

Bosworth, Barry, and Gary Burtless. 2004. Pension reform and saving. Paper presented at a conference of the International Forum of the Collaboration Projects, Tokyo, Japan.

Clark, Robert L., Naohiro Ogawa, and Rikiya Matsukura. 2008. Population decline, labor force stability. Paper presented at the Low Fertility Conference, University of St. Gallen, St. Gallen, Switzerland.

Costello, Declan, and Mandeep Bains. 2001. Budgetary challenges posed by ageing populations. Brussels, Belgium: Economic Policy Committee, European Economic Commission.

Diamond, Peter A., and Peter R. Orszag. 2004. Saving Social Security: A balanced approach. Washington, D.C.: Brookings Institution.

Engen, Eric M., William G. Gale, and John Karl Scholz. 1996. The illusory effects of savings incentives on saving. Journal of Economic Perspectives 10 (4): 113-38.

Feldstein, Martin. 1974. Social Security, induced retirement, and aggregate capital accumulation. Journal of Political Economy 82 (4): 905-26.

- 1982. Social Security and private savings: Reply. Journal of Political Economy 90 (3): 630-42.

. 1996. Social Security and private savings: New time series evidence. National Tax Journal 49 (2): 151-64.

Gale, William G. 2005. The effect of pensions and 401(k) plans on household saving and wealth. In The evolving pension: Trends, effects and proposals, ed. W. G. Gale, 
J. B. Shoven, and M. J. Warshawsky, 103-21. Washington, DC: Brookings Institution.

Goss, Steve, Alice Wade, and Jason Schultz. 2008. Unfunded obligations and transition cost for the OASDI program. Actuarial Note no. 2007, 1. Baltimore, MD: Office of the Chief Actuary, Social Security Administration.

Leimer, Dean R., and Selig D. Lesnoy. 1982. Social Security and private savings: New time series evidence. Journal of Political Economy 90 (3): 606-29.

Moore, James F., and Olivia S. Mitchell. 2000. Projected retirement wealth and savings adequacy. In Forecasting retirement needs and retirement wealth, ed. Olivia S. Mitchell, P. Brett Hammond, and Anna Rappaport, 68-94. Philadelphia: University of Pennsylvania Press.

Myerson, Harold. 2004. Good for investors, bad for the rest. Washington Post, January 14, 2004.

Nataraj, Sita, and John B. Shoven. 2004. Has the unified budget destroyed the Federal Government trust funds? Paper presented at conference sponsored by the Office of Policy, Social Security Administration and Michigan Retirement Research Consortium, Washington, DC.

Nyce, Steven A., and Sylvester J. Schieber. 2005. The economic implications of aging societies: The costs of living happily ever after. Cambridge, UK: Cambridge University Press.

Organization for Economic Cooperation and Development (OECD). 2001. Ageing and income. Paris: OECD.

Poterba, James. 2004. The impact of population aging on financial markets. NBER Working Paper no. 10851. Cambridge, MA: National Bureau of Economic Research.

Poterba, James, Steven Venti, and David A. Wise. 1993. Do 401(k) contributions crowd out other personal saving? NBER Working Paper no. 4391. Cambridge, MA: National Bureau of Economic Research.

1995. The effects of special saving programs on saving and wealth. NBER Working Paper no. 5287. Cambridge, MA: National Bureau of Economic Research.

. 1996. How retirement savings programs increase saving. Journal of Economic Perspectives 10 (4): 91-112.

. 2007. New estimates of the future path of 401(k) assets. NBER Working Paper no. 13083. Cambridge, MA: National Bureau of Economic Research.

President's Commission to Strengthen Social Security. 2001. Strengthening Social Security and creating personal wealth for all Americans: Final report of the President's Commission to Strengthen Social Security. Washington, DC: U.S. Government Printing Office.

Samuelson, Paul A. 1958. An exact consumption-loan model of interest with or without the social contrivance of money. Journal of Political Economy 66: 467-82.

Schieber, Sylvester J. 2008. The end of the golden years. Milken Quarterly Review (2nd quarter): 54-64.

Schieber, Sylvester J., and John B. Shoven. 1997. The consequences of population aging on private pension fund saving and asset markets. In Public policy toward pensions, ed. Sylvester J. Schieber and John B. Shoven, 219-46. Cambridge, MA: MIT Press.

Smetters, Kent. 2003. Is the Social Security trust fund worth anything? University of Pennsylvania. Unpublished Manuscript. 